\title{
44. HELIUM ISOTOPE RATIOS OF PORE GASES IN DEEP-SEA SEDIMENTS, LEG $128^{1}$
}

\author{
Yuji Sano, ${ }^{2,3}$ Minoru Sakamoto, ${ }^{2}$ Jun-ichiro Ishibashi, ${ }^{2}$ Hiroshi Wakita, ${ }^{2}$ and Ryo Matsumoto ${ }^{4}$
}

\begin{abstract}
We have measured the ${ }^{3} \mathrm{He} /{ }^{4} \mathrm{He}$ and ${ }^{4} \mathrm{He} /{ }^{20} \mathrm{Ne}$ ratios and chemical compositions of gases exsolved from deep-sea sediments at two sites (798 and 799) in the Japan Sea. The ${ }^{3} \mathrm{He} /{ }^{4} \mathrm{He}$ and ${ }^{4} \mathrm{He} /{ }^{20} \mathrm{Ne}$ ratios vary from $0.642 \mathrm{R}_{\text {atm }}$ (where $\mathrm{R}_{\text {atm }}$ is the atmospheric ${ }^{3} \mathrm{He} /{ }^{4} \mathrm{He}$ ratio of $1.393 \times 10^{-6}$ ) to $0.840 \mathrm{R}_{\mathrm{atm}}$, and from 0.41 to 4.5 , respectively. Helium in the samples can be explained by the mixing between atmospheric helium dissolved in bottom water of the Japan Sea and crustal helium in the sediment. The sedimentary helium is enriched in mantle-derived ${ }^{3} \mathrm{He}$ compared with those from the Japan Trench and the Nankai Trough. This suggests that the basement of the Japan Sea has relatively large remnants of mantle-derived helium compared with that of the Pacific. Major chemical compositions of the samples are methane and nitrogen. There is a positive correlation between methane content and helium content corrected for air component. Based on the ${ }^{3} \mathrm{He} /{ }^{4} \mathrm{He}-\Sigma \mathrm{C} /{ }^{3} \mathrm{He}$ diagram, the major part of methane can be attributed to crustal and/or organic origin.
\end{abstract}

\section{INTRODUCTION}

Helium flux from the solid Earth may provide significant constraints on the atmospheric helium budget (Sano, 1986; Torgersen, 1989 ) and heat production in the crust (O'Nions and Oxburgh, 1983; Oxburgh and O'Nions, 1987). The isotopic composition, the ${ }^{3} \mathrm{He} /{ }^{4} \mathrm{He}$ ratio shows a close relation to the geotectonic features of the region where the sample was collected (Tolstikhin, 1978). Various kinds of gas and fluid were analyzed to understand the origin of helium. One could observe higher ${ }^{3} \mathrm{He} /{ }^{4} \mathrm{He}$ ratios than that of atmospheric helium in volcanic and tectonically active regions while the lower ratios were generally found in continental regions where magmatic and orogenic activities are low. Although more than 2000 measurements were carried out on land (Mamyrin and Tolstikhin, 1984), the number of helium isotope data in oceanic sediments is small. This is partly due to difficulty in collecting gas samples from sediment cores.

The helium isotope signature of mid-ocean ridge basalt (MORB) is now well documented (Lupton, 1983). Their high and uniform values are considered to be juvenile helium that represents the Earth's upper mantle. On the other hand, pore water and gas in deep-sea sediments may give important information on ordinary ocean floor. Barnes and Clarke (1987) discussed fluid kinematics, fluid residence times, and rock degassing in oceanic crust based on helium isotope ratios and noble gas contents of sedimentary pore fluids. They found that the most juvenile helium is degassed from the oceanic crust within $6 \times 10^{5} \mathrm{yr}$ after its formation. Sano and Wakita (1987) reported that there is a positive correlation between ${ }^{3} \mathrm{He} /{ }^{4} \mathrm{He}$ ratios and terrestrial heat flow values in the Pacific Ocean. Both decrease with increasing distance from the East Pacific Rise. The result was explained by a conventional seafloor spreading model (McKenzie, 1967). When oceanic crust is new and hot, its emissions of both heat and ${ }^{3} \mathrm{He}$ are relatively large. During aging of the crust, emissions decrease significantly due to the depletion of mantle-derived heat and ${ }^{3} \mathrm{He}$ in the source.

The Japan Sea is a typical marginal sea in terms of geography, geology, and geophysics (Matsuda and Uyeda, 1971; Uyeda and

\footnotetext{
' Pisciotto, K. A., Ingle, J. C., Jr., von Breymann, M. T., Barron, J., et al., 1992. Proc. $O D P$, Sci. Results, 127/128, Pt. 1: College Station, TX (Ocean Drilling Program).

2 Laboratory for Earthquake Chemistry, Faculty of Science, The University of Tokyo, Bunkyo-ku, Tokyo 113, Japan.

${ }^{3}$ Present address: Institute of Geology and Mineralogy, Faculty of Science, Hiroshima University, Kagamiyama, Higashi Hiroshima 724, Japan.

${ }^{4}$ Geological Institute, Faculty of Science. The University of Tokyo, Bunkyo-ku, Tokyo 113, Japan.
}

Kanamori, 1979). The marginal sea was created by rifting and seafloor spreading behind the Japanese Islands. Recent geochronological studies revealed that the opening of the Japan Sea might have started between 17 and $25 \mathrm{Ma}$ before present (Kaneoka et al., 1990). Thus, the formation age of the oceanic crust of this marginal sea is significantly younger than that of the oceanic crust close to Japan in the Pacific, especially the Japan Trench. As pore gases in deep-sea sediments would trap some volatiles degassed from the oceanic crust beneath the sediment, there may be a difference in helium isotope ratios between samples from the Japan Sea and the Pacific. This paper is primarily concerned with the helium isotope signature of pore gases in sediments from the Japan Sea. In addition, we will discuss the origin of methane in the samples based on the relation between helium isotope and total carbon to ${ }^{3} \mathrm{He}$ ratios.

\section{EXPERIMENTAL PROCEDURE}

When the core samples in the plastic liner reached room temperature on deck, they began to swell slightly because of increasing pressure due to gases released from the sediments in the liner. Gas in the liner was sucked out and collected carefully by means of a glass syringe with stainless steel needle. A lead-glass container with vacuum valves at both ends was filled with deionized water in a pail. The syringe-containing gas sample was connected to the lead-glass container in the pail using thick-wall Tygon tubing. Then gas was introduced into the container, displacing water in it, and both valves were closed. The samples were stored for a couple of months. Because the permeation velocity of helium in lead-glass is low, penetration of atmospheric helium is negligibly small.

In the laboratory, about $0.5 \mathrm{~cm}^{3} \mathrm{STP}$ of gas sample was introduced into a metallic high-vacuum line. Helium and neon were purified using hot $\mathrm{Ti}-\mathrm{Zr}$ getters and activated charcoal traps held at $77 \mathrm{~K}$. The ${ }^{4} \mathrm{He} /{ }^{20} \mathrm{Ne}$ ratios were measured by a quadrupole mass spectrometer (QMG112, Balzers). Then helium was separated from neon using a cryogenic charcoal trap held at $40 \mathrm{~K}$ and the ${ }^{3} \mathrm{He} /{ }^{4} \mathrm{He}$ ratios were measured statically by a branch tube mass spectrometer (a modified version of the VG5400, VG Isotopes). Resolving power of about 550 at $5 \%$ peak height was attained for complete separation of the ${ }^{3} \mathrm{He}$ beam from those of $\mathrm{H}_{3}+$ and $\mathrm{HD}$. Observed ${ }^{3} \mathrm{He} /{ }^{4} \mathrm{He}$ ratios were calibrated using an atmospheric helium standard. A detailed description of the measurement procedures has been given elsewhere (Sano and Wakita, 1988).

Chemical compositions of gas samples were determined using a second quadrupole mass spectrometer. Quadrupole mass spectrometry has several advantages over conventional gas chromatography: 
(1) Time elapsed for actual analysis in the system is less than 10 min for each sample, significantly shorter than that of the gas chromatography; (2) One does not need to prepare any carrier gas; and (3) it is possible to analyze the sample without any enrichment procedure using a Toepler pump, even though sample original pressure is less than 50 Torr in the container. The quadrupole mass spectrometer system has a few disadvantages as well. Due to cracking of $\mathrm{CO}_{2}$ in the ion source, $\mathrm{N}_{2}$ measurement is interfered with by $\mathrm{CO}$ having the same mass number. However, this can be corrected by verifying the doubly charged ion of $\mathrm{N}_{2}++$ and the isotope peak of ${ }^{14} \mathrm{~N}^{15} \mathrm{~N}$.

About $0.3 \mathrm{~cm}^{3}$ STP of the sample was admitted into a metallic vacuum line. The absolute amount of the sample was determined by high-precision pressure sensor (621A-10T, Edwards) after removing water vapor at $-45^{\circ} \mathrm{C}$. Then a small portion of the sample was dynamically introduced into a quadrupole mass spectrometer (MSQ101, UIVAC) through a variable leak valve (951-5106, Varian). The mass number was steadily scanned and the beam intensity was simultaneously measured by a digital voltmeter. Chemical components were determined by comparing peak heights of the sample with those of standard gases. Experimental errors were estimated to be about $\pm 10 \%$ by repeated measurements of standard samples. The dynamic backgrounds of the system for $\mathrm{He}, \mathrm{CH}_{4}, \mathrm{~N}_{2}, \mathrm{Ar}$, and $\mathrm{CO}_{2}$ were negligibly small compared to the signals of actual samples.

\section{RESULTS}

We obtained one pore-gas sample at Hole 798A and four samples at Hole $799 \mathrm{~A}$. The observed ${ }^{3} \mathrm{He} /{ }^{4} \mathrm{He}$ and ${ }^{4} \mathrm{He} /{ }^{20} \mathrm{Ne}$ ratios, and sampling depth are listed in Table 1 together with reported data of Site 584 in the Japan Trench and Site 583 in the Nankai Trough (Sano and Wakita, 1985). Also indicated are data of bottom water in the eastern Japan Sea (Sano et al., 1989), Pacific bottom water in the Nankai Trough (Igarashi et al., 1987), that in the Japan Trench (Barnes and Clarke, 1987), and air-saturated water at $20^{\circ} \mathrm{C}$ (Benson and Krouse, 1980: Top et al., 1987). Errors assigned to the isotope ratio determinations are one standard deviation. Errors of ${ }^{4} \mathrm{He} /{ }^{20} \mathrm{Ne}$ ratio measurements are estimated to be less than $10 \%$ by repeated measurements of air standard. Chemical compositions of the pore-gas samples are listed in Table 2. The samples from Site 799A are mixtures of $\mathrm{CH}_{4}$ and $\mathrm{N}_{2}$ while that of Site 798A shows atmospheric signature including $\mathrm{O}_{2}$ and $\mathrm{Ar}$. The 798A sample may be contaminated by air during the sampling procedure on deck.

The ${ }^{3} \mathrm{He} /{ }^{4} \mathrm{He}$ and ${ }^{4} \mathrm{He} /{ }^{20} \mathrm{Ne}$ ratios of samples from the Japan Sea vary from $0.642 \mathrm{R}_{\mathrm{atm}}$ (where $\mathrm{R}_{\mathrm{atm}}$ is the atmospheric ${ }^{3} \mathrm{He} /{ }^{4} \mathrm{He}$ ratio, $1.393 \times 10^{-6}$; Davidson and Emerson, 1990) to $0.840 \mathrm{R}_{\mathrm{atm}}$, and from 0.41 to 4.5 , respectively. Figure 1 shows a negative correlation between ${ }^{3} \mathrm{He} /{ }^{4} \mathrm{He}$ and ${ }^{4} \mathrm{He} /{ }^{20} \mathrm{Ne}$ ratios in the samples. A similar correlation was found in the Pacific samples from the Japan Trench (Site 584) and the Nankai Trough (Site 583) even though the slope is steeper in the Pacific than in the Japan Sea (Fig. 1). The trend is well explained by mixing between the noble gas component with relatively high ${ }^{3} \mathrm{He} /{ }^{4} \mathrm{He}$ and low ${ }^{4} \mathrm{He} /{ }^{20} \mathrm{Ne}$ ratios and that with low ${ }^{3} \mathrm{He} /{ }^{4} \mathrm{He}$ and high ${ }^{4} \mathrm{He} /{ }^{20} \mathrm{Ne}$ ratios.

\section{DISCUSSION}

Sano and Wakita (1987) reported that four end members are needed to interpret the ${ }^{3} \mathrm{He} /{ }^{4} \mathrm{He}$ and ${ }^{4} \mathrm{He} /{ }^{20} \mathrm{Ne}$ ratios in pore water and gases in Pacific deep-sea sediments. The first and second components with relatively high ${ }^{3} \mathrm{He} /{ }^{4} \mathrm{He}$ and low ${ }^{4} \mathrm{He} /{ }^{20} \mathrm{Ne}$ ratios were ascribed to air-saturated seawater and air-saturated water with a slight addition of mantle-derived ${ }^{3} \mathrm{He}$, respectively. Existence of the latter component was suggested in the GEOSECS Expedition Atlas (1987) and confirmed by Barnes and Clarke (1987) and Igarashi et al. (1987). The third and fourth end members were attributed to in-situ radiogenic helium and trapped helium from the degassing of the basement rock beneath the sediments, respectively. The contribution from cosmo-
Table $1 .{ }^{3} \mathrm{He} /{ }^{4} \mathrm{He}$ and ${ }^{4} \mathrm{He} /{ }^{20} \mathrm{Ne}$ ratios of gases exsolved from deep-sea sediments.

\begin{tabular}{|c|c|c|c|}
\hline Site & $\begin{array}{l}\text { Depth } \\
\text { (mbsf) }\end{array}$ & $\begin{array}{l}{ }^{3} \mathrm{He} /{ }^{4} \mathrm{He} \\
\left(\mathrm{R} / \mathrm{R}_{\text {atm }}\right)\end{array}$ & ${ }^{4} \mathrm{He} /{ }^{20} \mathrm{Ne}$ \\
\hline \multicolumn{4}{|l|}{ Japan Sea } \\
\hline \multicolumn{4}{|l|}{$128-$} \\
\hline $798 \mathrm{~A}-14 \mathrm{H}-4$ & 127 & $0.807 \pm 0.009$ & 0.41 \\
\hline $799 A-4-3$ & 23.5 & $0.840 \pm 0.009$ & 0.52 \\
\hline $799 \mathrm{~A}-13-4$ & 111.5 & $0.741 \pm 0.009$ & 3.5 \\
\hline $799 \mathrm{~A}-25$ & 227 & $0.642 \pm 0.008$ & 0.68 \\
\hline $799 \mathrm{~A}-50$ & 457 & $0.708 \pm 0.009$ & 4.5 \\
\hline \multicolumn{4}{|l|}{ Nankai Trough ${ }^{\mathrm{a}}$} \\
\hline \multicolumn{4}{|l|}{$87-$} \\
\hline 583D-8-2 & 123.5 & $0.706 \pm 0.026$ & 0.37 \\
\hline 583D-14 & 172 & $0.706 \pm 0.024$ & 0.41 \\
\hline $583 D-18$ & 220.0 & $0.425 \pm 0.020$ & 1.1 \\
\hline $583 \mathrm{D}-24$ & 278.4 & $0.461 \pm 0.013$ & 0.82 \\
\hline 583D-29 & 326.6 & $0.493 \pm 0.021$ & 0.83 \\
\hline $583 \mathrm{~F}-2$ & 169.6 & $0.276 \pm 0.014$ & 3.8 \\
\hline $583 \mathrm{~F}-7$ & 217.7 & $0.556 \pm 0.038$ & 0.43 \\
\hline $583 \mathrm{~F}-18$ & 323.9 & $0.879 \pm 0.014$ & 0.41 \\
\hline \multicolumn{4}{|l|}{ Japan Trench ${ }^{\mathrm{a}}$} \\
\hline \multicolumn{4}{|l|}{87.} \\
\hline $584-8$ & 77 & $0.236 \pm 0.007$ & 2.5 \\
\hline $584-16$ & 153.7 & $0.771 \pm 0.021$ & 0.43 \\
\hline $584-30-5$ & 287 & $0.154 \pm 0.006$ & 20 \\
\hline \multicolumn{2}{|c|}{ Japan Sea Bottom Water ${ }^{\mathrm{b}}$} & $1.045 \pm 0.010$ & 0.31 \\
\hline \multicolumn{2}{|c|}{ Pacific Bottom Water (1) } & $0.957-1.078$ & $0.29-0.49$ \\
\hline \multicolumn{2}{|c|}{ Pacific Bottom Water (2) ${ }^{d}$} & 1.13 & 0.26 \\
\hline \multicolumn{2}{|c|}{ Air-Saturated Water at $20^{\circ} \mathrm{C}$} & $0.9837^{\circ}$ & $0.2665^{f}$ \\
\hline
\end{tabular}

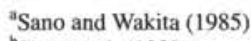

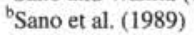

${ }^{c}$ Igarashi et al. (1987)

${ }^{\mathrm{d}}$ Barnes and Clarke (1987)

${ }^{\mathrm{e}}$ Benson and Krause (1980)

Table 2. Chemical compositions of gases exsolved from deep-sea sediments.

\begin{tabular}{lccccccc}
\hline \multicolumn{1}{c}{ Site } & $\begin{array}{c}\mathrm{He} \\
(\mathrm{ppm})\end{array}$ & $\begin{array}{c}\mathrm{CH}_{4} \\
(\%)\end{array}$ & $\begin{array}{c}\mathrm{N}_{2} \\
(\%)\end{array}$ & $\begin{array}{c}\mathrm{C}_{2} \mathrm{H}_{6} \\
(\mathrm{ppm})\end{array}$ & $\begin{array}{c}\mathrm{O}_{2} \\
(\%)\end{array}$ & $\begin{array}{c}\mathrm{Ar} \\
(\%)\end{array}$ & $\begin{array}{l}\mathrm{CO}_{2} \\
(\%)\end{array}$ \\
\hline Japan Sea & & & & & & & \\
128- & & & & & & & \\
798A-14H-4 & 8.5 & 0.23 & 86 & $<10$ & 9.0 & 0.85 & 3.9 \\
$799 \mathrm{~A}-4-3$ & 12 & 17 & 80 & 100 & 0.01 & 0.99 & 2.8 \\
799A-13-4 & 8.8 & 64 & 33 & 200 & 0.03 & 0.45 & 3.0 \\
799A-25 & 10 & 20 & 70 & 100 & 0.03 & 1.2 & 8.7 \\
$799 A-50$ & 13 & 85 & 14 & 400 & 0.02 & 0.26 & 0.78 \\
\hline
\end{tabular}

genic helium in the solid phase of pelagic sediments was negligibly small (Barnes and Clarke, 1987; Sano and Wakita, 1987). Thus, the mixing ratio of the radiogenic and trapped helium as well as the variable ${ }^{3} \mathrm{He} /{ }^{4} \mathrm{He}$ ratio in the trapped helium could define the slope of the samples in Fig. 1.

Assuming that the ${ }^{4} \mathrm{He} /{ }^{20} \mathrm{Ne}$ ratios of the radiogenic and trapped helium are significantly higher than those of the first and second components, it is possible to correct atmospheric helium components as follows:

$$
\begin{aligned}
\left({ }^{3} \mathrm{He} /{ }^{4} \mathrm{He}\right)_{\mathrm{cor}} & =\left[\left({ }^{3} \mathrm{He} /{ }^{4} \mathrm{He}\right)_{\mathrm{obs}}-\left({ }^{3} \mathrm{He} /{ }^{4} \mathrm{He}\right)_{\text {air }} \times r\right] /(1-r) \\
r & =\left({ }^{4} \mathrm{He} /{ }^{20} \mathrm{Ne}\right)_{\text {air }} /\left({ }^{4} \mathrm{He} /{ }^{20} \mathrm{Ne}\right)_{\text {obs }}
\end{aligned}
$$

Where $\left({ }^{3} \mathrm{He} /{ }^{4} \mathrm{He}\right)_{\mathrm{cor}}$ and $\left({ }^{3} \mathrm{He} /{ }^{4} \mathrm{He}\right)_{\text {obs }}$ denote the corrected and observed ${ }^{3} \mathrm{He} /{ }^{4} \mathrm{He}$ ratios normalized to $\mathrm{R}_{\text {atm }}$, and $\left({ }^{4} \mathrm{He} /{ }^{20} \mathrm{Ne}\right)_{\text {air }}$ and $\left({ }^{4} \mathrm{He} /{ }^{20} \mathrm{Ne}\right)_{\text {obs }}$ are the atmospheric and observed ${ }^{4} \mathrm{He} /{ }^{20} \mathrm{Ne}$ ratios, respectively. Considering 


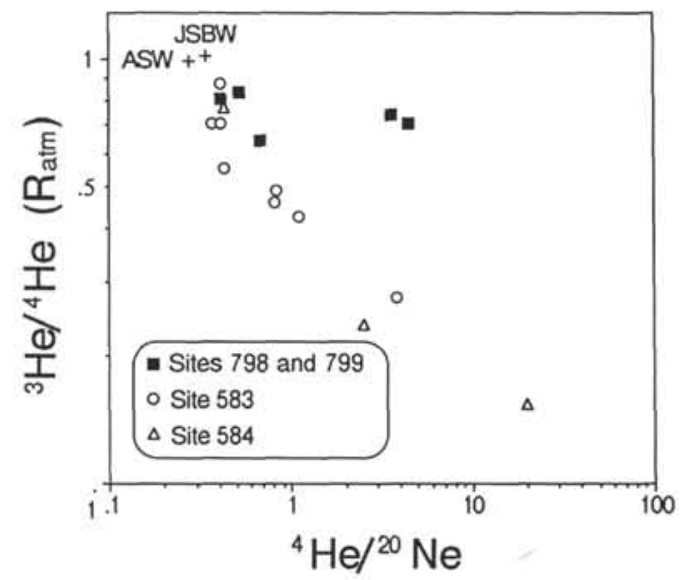

Figure 1. Correlation between the ${ }^{3} \mathrm{He} /{ }^{4} \mathrm{He}$ and ${ }^{4} \mathrm{He} /{ }^{20} \mathrm{Ne}$ ratios for pore-gas samples. Data of Sites 583 and 584 are from Sano and Wakita (1985). JSBW and ASW show Japan Sea bottom water and air-saturated water, respectively. Note that the crustal end member of the Japan Sea samples is different from those of the Pacific samples.

reported values in Table 1 , we assume 0.31 and 1.045 for $\left({ }^{4} \mathrm{He} /{ }^{20} \mathrm{Ne}\right)$ air and $\left({ }^{3} \mathrm{He} /{ }^{4} \mathrm{He}\right)_{\text {air }}$ values of the Japan Sea samples, respectively. For the Pacific samples, values of 0.26 for $\left({ }^{4} \mathrm{He} /{ }^{20} \mathrm{Ne}\right)_{\text {air }}$ and 1.13 for $\left({ }^{3} \mathrm{He} /{ }^{4} \mathrm{He}\right)_{\text {air }}$ are assumed. If the $\left({ }^{4} \mathrm{He} /{ }^{20} \mathrm{Ne}\right)_{\text {obs }}$ value is equivalent to the $\left({ }^{4} \mathrm{He} /{ }^{20} \mathrm{Ne}\right)_{\text {air }}$ value, it is impossible to obtain a result, as the denominator in the right side of equation (1) equals 0 . When the $\left({ }^{4} \mathrm{He}{ }^{20} \mathrm{Ne}\right)_{\text {obs }}$ value approaches the $\left({ }^{4} \mathrm{He}{ }^{20} \mathrm{Ne}\right)_{\text {air }}$ value, the estimated result is significantly error. Therefore, we calculated the $\left({ }^{3} \mathrm{He} /{ }^{4} \mathrm{He}\right)_{c o r}$ value only for samples with the $\left({ }^{4} \mathrm{He} /{ }^{20} \mathrm{Ne}\right)_{\text {obs }}$ values larger than 1 . Corrected ${ }^{3} \mathrm{He} /{ }^{4} \mathrm{He}$ ratios are listed in Table 3 together with those of Sites 436 and 438 in the Japan Trench (Barnes and Clarke, 1987). These values could be a mixture of the radiogenic and the trapped helium, as the atmospheric component is now eliminated. We note that Site 436 shows a higher ${ }^{3} \mathrm{He} /{ }^{4} \mathrm{He}$ ratio than that of air. There is a substantial contribution from mantle-derived helium at this site.

Barnes and Clarke (1987) suggested that tensile stress in the upper lithosphere caused by flexure over the seaward swell can propagate cracks and faults into the upper mantle, providing localized conduits for deep fluid circulation and the release of juvenile volatiles from the mantle. However, the mechanism to produce high ${ }^{3} \mathrm{He} /{ }^{4} \mathrm{He}$ ratio is not well understood. Site 438 on the landward wall of the Japan Trench shows higher ${ }^{3} \mathrm{He} /{ }^{4} \mathrm{He}$ ratios than those of Site 584 , about $35 \mathrm{~km}$ downslope from Site 438. The higher ratios are attributed to horizontal fluid transport with the influence of volatiles from old continental crust and the volcanic arc (Barnes and Clarke, 1987). Except for Site 436, the Japan Sea samples indicate the highest ${ }^{3} \mathrm{He} /{ }^{4} \mathrm{He}$ ratios and the youngest formation age is estimated in the Japan Sea (Table 3). This suggests that the trapped helium from the basement is a dominant component in the sample. To verify the idea, we should consider radiogenic helium isotopes in the deep-sea sediments.

The isotopic signature of radiogenic helium depends on the rates of ${ }^{3} \mathrm{He}$ and ${ }^{4} \mathrm{He}$ production. Production rate of radiogenic ${ }^{4} \mathrm{He}$ in the Pacific samples may be similar to that of the Japan Sea samples, as U and Th contents of the sediments in the Pacific are almost identical to those in the Japan Sea (Minai et al., 1985; Minai et al., this volume). Radiogenic production rate of ${ }^{3} \mathrm{He}$ is due to the contents of $\mathrm{Li}$ and other light elements such as $\mathrm{O}, \mathrm{Si}, \mathrm{Al}, \mathrm{K}$, and $\mathrm{B}$. There is not a significant difference of major-element chemistry between the Pacific and the Japan Sea samples (Minai et al., 1985; Minai et al., this volume). The ${ }^{3} \mathrm{He}$ production in the Pacific samples may also be similar to that of the Japan Sea. The radiogenic ${ }^{3} \mathrm{He} /{ }^{4} \mathrm{He}$ ratio of the Japan Sea sediments cannot be distinguished from that of the Pacific sediments. Therefore, relatively high $\left({ }^{3} \mathrm{He} /{ }^{4} \mathrm{He}\right)_{\mathrm{cor}}$ values of the Japan Sea samples may be attributable to the high ${ }^{3} \mathrm{He} /{ }^{4} \mathrm{He}$ ratio of the trapped helium in the sediment degassed from basement rocks. The formation age of the Japan Sea site is significantly younger than those of the Pacific sites (Table 3). The basement of the Japan Sea site may have a relatively large remnant of mantle-derived helium. This is the probable reason for the difference in $\left({ }^{3} \mathrm{He} /{ }^{4} \mathrm{He}\right)_{\text {cor }}$ values in the Japan Sea and the Pacific.

\begin{tabular}{|c|c|c|}
\hline Site & Formation & $\begin{array}{c}{ }^{3} \mathrm{He}^{4}{ }^{4} \mathrm{He}_{\mathrm{co}} \\
\left(\mathrm{R} / \mathrm{R}_{\mathrm{atm}}\right)\end{array}$ \\
\hline \multicolumn{3}{|l|}{ Japan Sea } \\
\hline \multicolumn{3}{|l|}{128} \\
\hline 799A-13-4 & Miocene & 0.71 \\
\hline $799 \mathrm{~A}-50$ & Miocene & 0.68 \\
\hline \multicolumn{3}{|l|}{ Nankai Trough } \\
\hline \multicolumn{3}{|l|}{87} \\
\hline $583 \mathrm{D}-18^{\mathrm{a}}$ & late Eocene & 0.21 \\
\hline $583 \mathrm{~F}-2^{\mathrm{a}}$ & late Eocene & 0.21 \\
\hline \multicolumn{3}{|l|}{ Japan Trench } \\
\hline \multicolumn{3}{|l|}{ 87. } \\
\hline $\begin{array}{l}584-8^{a} \\
584-30-5^{a}\end{array}$ & $\sim$ Cretaceous & 0.13 \\
\hline $57438^{\mathrm{b}}$ & $\sim$ Cretaceous & 0.14 \\
\hline 56 & $\sim$ Cretaceous & $0.52-0.54$ \\
\hline $436^{b}$ & early Cretaceous & $2.2-3.1$ \\
\hline
\end{tabular}

\section{ORIGIN OF METHANE}

Origin of methane-rich natural gases has been elucidated by several researchers (Hunt, 1979; Tissot and Welte, 1984). The biogenic hypothesis has been widely accepted in view of evidence from carbon isotope, microfossil, and pyrolysis studies. On the other hand, some scientists in the U.S.S.R. and eastern Europe reported an abiogenic hypothesis of hydrocarbon gas production (Porfir'ev, 1974; Petersil'ye and Pavlova, 1978). Recently Wakita et al. (1990) proposed an abiogenic origin for methane-rich natural gas in deepseated "Green Tuff" reservoirs in Japan (large volcaniclastic reservoirs formed by large-scale submarine volcanism during the middle Miocene) based on the high ${ }^{3} \mathrm{He} /{ }^{4} \mathrm{He}$ ratio, the low total $\mathrm{C}$ to ${ }^{3} \mathrm{He}\left(\Sigma \mathrm{C}^{\beta} \mathrm{He}\right)$ ratio and the low $\delta^{13} \mathrm{C}$ value. On the other hand, the origin of natural gas in shallow reservoirs in sedimentary formations is inferred to be of biogenic origin. Wakita et al. (1990) noted that the formation of "Green Tuff" magmatism may be related to the opening of the Japan Sea in the middle Miocene. Because Sites 798 and 799 are located in the Japan Sea, the pore gases in the sediments might be influenced by either the abiogenic "Green Tuff" gas or the biogenic natural gas found in the shallow reservoir. The ${ }^{3} \mathrm{He} /{ }^{4} \mathrm{He}$ and the $\Sigma \mathrm{C} /{ }^{3} \mathrm{He}$ ratios may provide significant constraints on the origin of methane in the pore gases.

Dominant chemical constituents of the pore gases at Sites 798 and 799 are nitrogen and methane (Table 2). There are no significant correlations between helium and nitrogen or methane contents. This may be due to the contribution of helium derived from the atmosphere. The air component is easily eliminated as follows:

$$
[\mathrm{He}]_{\mathrm{cor}}=(1-r) \times[\mathrm{He}]_{\mathrm{obs}}
$$

where $[\mathrm{He}]_{\mathrm{cor}}$ and $[\mathrm{He}]_{\mathrm{obs}}$ denote the corrected and observed helium contents, and $r$ was defined in equation (2). Figure 2 shows the relation between the corrected and observed helium, and methane 


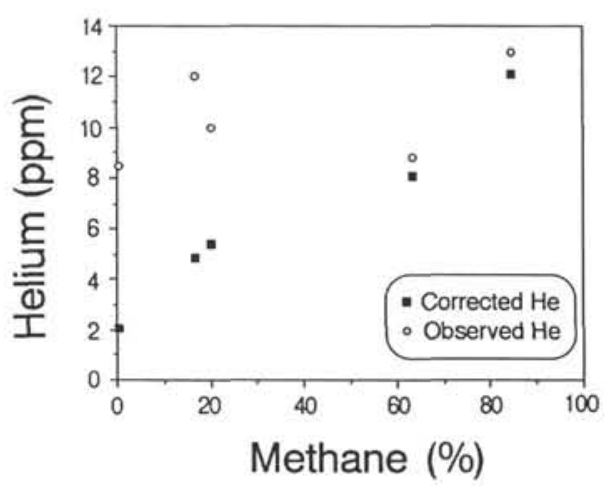

Figure 2. Correlation between methane and helium contents in pore-gas samples. Open circles and solid squares show observed and corrected helium contents, respectively, for the air component.

contents in the pore gas samples. There is a linear correlation between the corrected helium and methane contents. Consider the data in Table 2 . The methane concentration shows a negative correlation with the nitrogen content while the corrected helium concentration indicates a negative correlation with nitrogen content. This means that the helium accompanying methane is later diluted by nitrogen. Origin of the methane may be related to that of helium, with the ${ }^{3} \mathrm{He} /{ }^{4} \mathrm{He}$ ratio of about $0.7 R_{\text {atm }}$ (see Table 3 ).

Figure 3 indicates the relation between the ${ }^{3} \mathrm{He} /{ }^{4} \mathrm{He}$ ratio and the total carbon to ${ }^{3} \mathrm{He}\left(\Sigma \mathrm{C} /{ }^{3} \mathrm{He}\right)$ ratio in the pore-gas samples. Data from methane-rich natural gas, "Green Tuff' gas, and volcanic gas in Japan are also shown (Marty et al., 1989; Wakita et al., 1990). There is a general trend in the diagram. The ${ }^{3} \mathrm{He} /{ }^{4} \mathrm{He}$ ratio decreases with increasing $\Sigma \mathrm{C} /{ }^{3} \mathrm{He}$ ratio. The "Green Tuff" gas with high ${ }^{3} \mathrm{He} /{ }^{4} \mathrm{He}$ and low $\Sigma \mathrm{C} /{ }^{3} \mathrm{He}$ ratios was attributed to magmatic origin while the natural gas with low ${ }^{3} \mathrm{He} /{ }^{4} \mathrm{He}$ and high $\Sigma \mathrm{C} /{ }^{3} \mathrm{He}$ ratios was due to biogenic and/or crustal origin (Wakita et al., 1990). Data from pore gas in the Japan Sea are locating somewhat lower than the general trend but almost between the "Green Tuff" gas and the natural gas in Fig. 3. This suggests that the pore gas is a mixture of "Green Tuff" gas and natural gas. However the contribution of the "Green Tuff" gas may be considerably small, as the $\Sigma \mathrm{C}^{\beta} \mathrm{He}$ ratio of

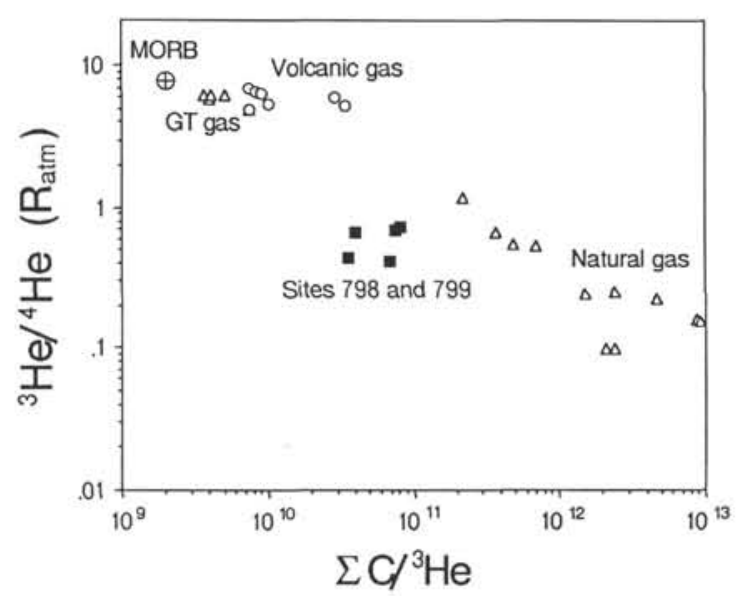

Figure 3. Correlation between the ${ }^{3} \mathrm{He} /{ }^{4} \mathrm{He}$ and the total carbon to ${ }^{3} \mathrm{He}\left(\Sigma \mathrm{C} /{ }^{3} \mathrm{He}\right)$ ratios in pore-gas samples. GT gas and MORB indicate "Green Tuff" gas and mid-ocean ridge basalt, respectively. Volcanic gas and methane-rich natural gas in Japan are also shown (Marty et al., 1989; Wakita et al., 1990). the pore gas is 10 times larger than that of the "Green Tuff" gas. A significant fraction of methane in the pore gas can be attributed to biogenic and/or crustal origin.

In conclusion, the ${ }^{3} \mathrm{He} /{ }^{4} \mathrm{He}$ ratio of pore gas in the sediment of the Japan Sea is principally of crustal origin and shows slightly higher values than that of the Japan Trench and the Nankai Trough in the Pacific. This implies that the basement of the Japan Sea has relatively large remnants of mantle-derived helium compared with that of the Pacific.

\section{ACKNOWLEDGMENTS}

We thank the editor and two anonymous reviewers for providing valuable comments on the original manuscript.

\section{REFERENCES}

Barnes, R. O., and Clarke, W. B., 1987. Fluid kinematics, fluid residence times, and rock degassing in oceanic crust determined from noble gas contents of Deep Sea Drilling Project pore waters. J. Geophys. Res., 92:12491-12506.

Benson, B. B., and Krause, D., Jr., 1980. Isotope fractionation of helium during solution: a probe for the liquid state. J. Solution Chem., 9:895-909.

Davidson, T. A., and Emerson, D. E., 1990. Direct determination of helium-3 content of atmospheric air by mass spectrometer. J. Geophys. Res., 95:3563-3568.

GEOSECS Expedition Atlas, 1987. Shorebased Data: Washington, D.C. (U. S. Govt. Printing Office).

Hunt, J. M., 1979. Petroleum Geochemistry and Geology: (Freeman and Company).

Igarashi, G., Kodera, M., Ozima, M., Sano, Y., Wakita, H., and Boulègue, J., 1987. Noble gas elemental and isotopic abundances in deep-sea trenches in the western Pacific. Earth Planet. Sci. Lett., 86:77-84.

Kaneoka, I., Notsu, K., Takigami, Y., Fujioka, K., and Sakai, H., 1990. Constraints on the evolution of the Japan Sea based on ${ }^{40} \mathrm{Ar}-{ }^{39} \mathrm{Ar}$ ages and $\mathrm{Sr}$ isotopic ratios for volcanic rocks of the Yamato Seamount chain in the Japan Sea. Earth Planet. Sci. Lett., 97:211-225.

Lupton, J. E., 1983. Terrestrial inert gases: isotope tracer studies and clues to primordial components in the mantle. Annu. Rev. Earth Planet. Sci., $11: 371-414$.

Mamyrin, B. A., and Tolstikhin, I. N., 1984. Helium Isotopes in Nature: Amsterdam (Elsevier).

Marty, B., Jambon, A., and Sano, Y., 1989. Helium isotopes and $\mathrm{CO}_{2}$ in volcanic gases of Japan. Chem. Geol., 76:25-40.

Matsuda, T., and Uyeda, S., 1971. On the Pacific-type orogeny and its model-extension of the paired belts concept and possible origin of marginal seas. Tectonophysics, 11:5-27.

Minai, Y., Matsumoto, R., and Tominaga, T., 1985. Geochemistry of deep sea sediments from the Nankai Trough, the Japan Trench and adjacent regions. In Kagami, H., Karig, D. E., Coulbourn, W. T., et al., Init. Repts. DSDP, 87: Washington (U. S. Govt. Printing Office), 643-657.

McKenzie, D. P., 1967. Some remarks on heat flow and gravity anomalies. $J$. Geophys. Res., 72:6261-6271.

O'Nions, R. K., and Oxburgh, E. R., 1983. Heat and helium in the Earth. Nature, 306:429-431.

Oxburgh, E. R., and O'Nions, R. K., 1987. Helium loss, tectonics and the terrestrial heat budget. Science, 237:1583-1588.

Ozima, M., and Podosek, F. A., 1983. Noble Gas Geochemistry: Cambridge (Cambridge Univ. Press).

Petersil'ye, I. A., and Pavlova, M. A., 1978. Organic compounds in volcanic and metamorphic rocks. Int. Geol. Rev., 20:339-344.

Porfir'ev, V. B., 1974. Inorganic origin of petroleum. AAPG Bull., 58:3-33.

Sano, Y., 1986. Helium flux from the solid earth. Geochem. J., 21:227-232.

Sano, Y., and Wakita, H., $1985 .{ }^{3} \mathrm{He} /{ }^{4} \mathrm{He}$ ratios of pore gases in pore waters, sites 583 and 584. In Kagami, H., Karig, D. E., Coulbourn, W. T., et al., Init. Repts. DSDP, 87: Washington (U. S. Govt. Printing Office), 861-864. 1987. Helium isotopes and heat flow on the ocean floor. Chem. Geol. (Isot. Geosci. Sect.), 66:217-226.

, 1988. Precise measurement of helium isotopes in terrestrial gases. Bull. Chem. Soc. Jpn., 61:1153-1157.

Sano, Y., Wakita, H., and Sheng, X., 1988. Atmospheric helium isotope ratio. Geochem. J., 22:177-181. 
Sano, Y., Wakita, H., Ishibashi, J., Gamo, T., and Sakai, H., 1989. Helium isopote ratios in Japan Sea water. Chikyukagaku, 23:61-67.

Tissot, B. P., and Welte, D. H., 1984. Petroleum Formation and Occurrence: Berlin (Springer-Verlag).

Tolstikhin, I. N., 1978. Some recent advances in isotope geochemistry of light rare gases. In Alexander, E. C., and Ozima, M. (Eds.), Terrestrial Rare Gases. Jpn. Sci. Soc. Press. Adv. Earth Planet. Sci., 3:33-62.

Top, Z., Eismont, W. C., and Clarke, W. B., 1987. Helium isotope effect and solubility of helium and neon in distilled water and seawater. Deep Sea Res. Part A, 34:1139-1148.

Torgersen, T., 1989. Terrestrial helium degassing fluxes and the atmospheric helium budget: implications with respect to the degassing processes of continental crust. Chem. Geol. (Isot. Geosci. Sect.), 79:1-14.
Uyeda, S., and Kanamori, H., 1979. Back-arc opening and the mode of subduction. J. Geophys. Res., 84:1049-1061.

Wakita, H., Sano, Y., Urabe, A., and Nakamura, Y., 1990. Origin of methanerich natural gas in Japan: formation of gas fields due to large-scale submarine volcanism. Appl. Geochem., 5:263-278.

Date of initial receipt: 18 March 1991

Date of acceptance: 26 November 1991

Ms 127/128B-182 